\title{
Role of plant architecture on littoral macroinvertebrates in temperate and subtropical shallow lakes: a comparative manipulative field experiment
}

\author{
Juan M. Clemente ${ }^{1, *}$, Thomas Boll2 ${ }^{2}$, Franco Teixeira-de Mello ${ }^{1}$, Carlos Iglesias ${ }^{1}$, Asger Roer \\ Pedersen $^{3}$, Erik Jeppesen ${ }^{2,4}$ and Mariana Meerhoff ${ }^{1,2, *}$ \\ ${ }^{1}$ Departamento de Ecología y Gestión Ambiental, Centro Universitario Regional del Este, Universidad de la \\ República, Maldonado, Uruguay. \\ 2 Department of Bioscience, Aarhus University, Silkeborg, Denmark. \\ ${ }^{3}$ Hammel Neurorehabilitation Centre and University Research Clinic, Aarhus University, Hammel, Denmark. \\ ${ }^{4}$ Sino-Danish Centre for Education and Research, Beijing, China. \\ * Corresponding author: checho@fcien.edu.uy or merluz@fcien.edu.uy
}

Received: 23/07/2018 Accepted: 22/03/2019

\begin{abstract}
Role of plant architecture on littoral macroinvertebrates in temperate and subtropical shallow lakes: a comparative manipulative field experiment
\end{abstract}

We dedicate this paper to the late Maria Rosa Miracle, who was a key researcher in the shallow lakes community, always enthusiastically dedicated to science, and always ready to discuss and guide younger scientists and fellow colleagues on the dynamics of zooplankton as well as on shallow lakes functioning at large. She will be sadly missed.

Plant habitat complexity can buffer against predator-prey interactions by offering physical refuges, and also novel microhabitats for alternative prey. In shallow lakes, submerged and free-floating plants affect predator-prey interactions with expected differences related to climate-driven differences in fish community structure. We tested the overall hypothesis that fish predation shapes the structure of plant-associated macroinvertebrate communities. By introducing artificial free-floating and submerged plants in a total of 14 shallow lakes under contrasting climate regimes (temperate and subtropical), we predicted that higher densities of macroinvertebrates would occur in the temperate zone where littoral fish predation is comparatively weaker than in the subtropics. We also tested the hypothesis that different structural complexities and \% PVI would lead to different association patterns. Taxonomic richness, diversity, and densities of plant-attached macroinvertebrates were several fold higher in the temperate lakes. Macroinvertebrate densities per unit of plant weight were generally higher on the more complex free-floating than on the more abundant (as \% PVI) submerged plants. The structure of littoral macroinvertebrates showed no clear relationship with the trophic state gradient. Fish communities, whose structure (biomass, density and habitat use) differed consistently between the temperate and subtropical locations, seemingly shaped the macroinvertebrate communities, most likely via predation and in the subtropics potentially also by competition. Free-floating plants appeared as a better anti-predation refuge or a preferred habitat for macroinvertebrates, particularly in the subtropics, but with increasing water turbidity this pattern became less distinct. In contrast, in the temperate lakes, the use of artificial plants by macroinvertebrates was rather related to the biomass of periphyton than to their refuge capacity, thus suggesting stronger bottom-up effects. A stronger fish predation pressure, which is to be expected with climate warming and eutrophication, may reduce the richness and abundance of plant-associated macroinvertebrates, with potentially strong impacts on shallow lake functioning. A warming-driven expansion of free-floating plants could, if moderate, weaken such effects, but a more diverse macrophyte community would facilitate co-existence of macroinvertebrate and fish.

Key words: habitat complexity, space for time substitution, artificial plants, free-floating plants, fish predation 


\section{RESUMEN \\ Rol de la arquitectura de las plantas sobre los macroinvertebrados litorales en lagos someros templados y subtropicales: una comparación experimental de campo}

La complejidad del hábitat puede modular interacciones entre depredadores y presas al ofrecer refugio fisico y nuevos microhábitats para competidores potenciales o presas alternativas. En los lagos someros, las plantas sumergidas y flotantes afectan las interacciones depredador-presa, con diferencias relacionadas a diferencias en la comunidad de peces influenciadas por el clima. Mediante la introducción de plantas flotantes libres y plantas sumergidas artificiales en un total de 14 lagos someros en dos regímenes climáticos contrastantes (templado y subtropical), analizamos la hipótesis de que la estructura de la comunidad de macroinvertebrados litorales está principalmente determinada por la presión de depredación de los peces. Por lo tanto, esperamos encontrar mayores densidades en la zona templada, donde la depredación por parte de los peces litorales es comparativamente más débil que en la zona subtropical. También analizamos la hipótesis de que las diferencias en complejidad estructural (mayor en las flotantes), así como en volumen ocupado por plantas (mayor en las sumergidas) promueve diferentes patrones de asociación en los macroinvertebrados.

La riqueza taxonómica, la diversidad y la densidad de los macroinvertebrados litorales fueron varias veces mayores en los lagos templados. Las densidades de macroinvertebrados (por unidad de masa de las plantas) fueron en general mayores en las plantas flotantes libres. La estructura de los macroinvertebrados litorales no mostró una relación clara con el gradiente de estado trófico estudiado. Los peces, cuya biomasa, densidad y uso del hábitat difirieron de forma consistente entre ambas zonas, determinaron la estructura de los macroinvertebrados probablemente vía depredación y en la zona subtropical potencialmente también por competencia. Las plantas flotantes libres parecieron actuar como un refugio más efectivo o hábitat preferido particularmente en la zona subtropical, pero con el aumento de la turbidez del agua el patrón se hizo menos evidente. En los lagos templados, el uso del hábitat estuvo más vinculado a la biomasa de perifiton, sugiriendo la ocurrencia de controles ascendentes. Una mayor presión de consumo por los peces (esperada con el calentamiento climático y un aumento de la eutrofización), puede reducir la riqueza y abundancia de los macroinvertebrados litorales con impactos potencialmente fuertes sobre el funcionamiento de los lagos someros. Una expansión de las plantas flotantes libres promovida por el calentamiento climático, podría, si fuera moderada, debilitar estos efectos. Sin embargo, una comunidad diversa de macrófitas seguramente promovería la coexistencia entre macroinvertebrados y peces.

Palabras clave: complejidad de hábitat, sustitución tiempo por espacio, plantas artificiales, plantas flotantes libres, depredación por peces

\section{INTRODUCTION}

Our understanding of lake functioning advanced dramatically with the recognition that the littoral-benthic and pelagic food chains are often very strongly linked (e.g. Timms \& Moss, 1984; Vadeboncoeur et al., 2002; Schindler \& Scheuerell, 2002). By feeding in the littoral or benthic habitats, macroinvertebrates can transform and translocate organic matter and nutrients that ultimately reach fish and other top predators (Jones \& Waldron, 2003), thus impacting whole-lake energy dynamics.

Habitat complexity in the different lake zones may affect whole ecosystem processes, not least by modulating predator-prey interactions. Macrophytes may reduce the feeding efficiency of fish and serve as a refuge for macroinvertebrates against fish predation (Diehl \& Kornijóv, 1998) and for small and juvenile fish against piscivo- rous fish (Persson \& Crowder, 1998). Particularly in vegetation-free areas (Leppä et al., 2003), fish predation can reduce the density and biomass of benthic macroinvertebrates and alter community structure by reducing the density of the larger and more motile taxa (Mittelbach, 1988; Diehl \& Kornijów, 1998). The predation pressure of fish on macroinvertebrates can lead to trophic cascades that ultimately reach periphyton and macrophytes (Brönmark \& Vermaat, 1998), potentially influencing the environmental state (e.g. clear or turbid waters) of shallow lakes (Jones \& Sayer, 2003; Burks et al., 2006). Areas with macrophytes, therefore, often support a much higher biomass and diversity of macroinvertebrates than vegetation free areas (Hargeby et al., 1994; Boll et al., 2012). Besides acting as a refuge against predation, macrophytes support the growth of epiphyton that serves as an important food source for grazing macroinvertebrates 
(Jones et al., 1998). Oligochaetes and chironomids can substantially reduce epiphytic biomass (Cattaneo, 1983), but especially snails facilitate the growth of submerged macrophytes by removing epiphytes (Brönmark \& Vermaat, 1998; Jones et al., 1998).

The physical structure or architecture of macrophytes determines several components of habitat complexity and therefore influences the abundance and community structure of plant-associated macroinvertebrates. Their abundance is often higher on submerged than on floating-leaved (Cattaneo et al., 1998) and emergent macrophytes (van de Meutter et al., 2008). Besides, macrophytes with finely divided leaves often host a higher abundance of macroinvertebrates than macrophytes of simpler structure (Cheruvelil et al., 2002; Xie et al., 2006). Differences in macroinvertebrate densities between plant types may partly be explained by epiphyton production, because epiphyton biomass often increases with increasing plant complexity (Cattaneo et al., 1998; Hao et al., 2017).

The role of macrophytes for macroinvertebrates, not least their interaction with potential predators, has been elucidated in much more detail in shallow temperate lakes (Brönmark \& Vermaat, 1998; Jones \& Sayer, 2003, Boll et al., 2012) than in subtropical and tropical lakes (Meerhoff et al., 2007a; Thomaz et al., 2008; Teixeira-de Mello et al., 2016). However, a differential role of macrophyte architecture in several biotic interactions has been associated with climate-related differences in fish community structure. In (sub)tropical lakes, fish, particularly small species and individuals, occur in high abundances and are especially associated with submerged macrophytes (Meerhoff et al., 2007a; Teixeira-de Mello et al., 2009). Consequently, the refuge effect of submerged plants for zooplankton (Burks et al., 2006), for instance, is substantially less efficient in the subtropics (Meerhoff et al., 2007 b; González-Sagrario \& Balseiro, 2010) and Mediterranean lakes (Tavsanoğlu et al., 2015) than in similar lakes in the temperate zone.

Despite the importance of the effects produced by the physical structure of aquatic plants, no standardized methods to measure plant complexity exist, limiting comparisons among different plant species and ecosystems (reviewed in Kovalenko et al., 2012). The use of artificial plants with controlled physical complexity can help decrease natural variability and allow for more specific hypothesis testing. Although plastic plants can promote different colonization patterns from those occurring on natural plants, typical confounding factors can be limited by the introduction of the same habitat modules along a trophic state gradient.

Here, we explored how plant-associated macroinvertebrates were affected by plant architecture, submerged or free-floating, in shallow lakes under different environmental scenarios, in particular along a gradient in trophic state and contrasting climates (temperate, Denmark, and subtropical, Uruguay).

We tested the hypothesis that the fish predation pressure shapes the structure of plant-associated macroinvertebrate communities. We expected to find impoverished littoral macroinvertebrate assemblages in lakes with high fish

Table 1. Main limnological characteristics of the lakes where the habitat modules were introduced, showing mean and range values for the temperate and subtropical zones $(\mathrm{n}=7$ in each country). Principales características limnológicas de los 14 lagos donde se introdujeron los hábitats experimentales con plantas artificiales. Se muestran la media y el rango de los valores para los lagos templados y los lagos subtropicales ( $n=7$ en cada país).

\begin{tabular}{c|ccccccc}
\hline & Area $(\mathrm{ha})$ & $\mathrm{T}\left({ }^{\circ} \mathrm{C}\right)$ & $\mathrm{SD}(\mathrm{m})$ & $\mathrm{pH}$ & $\mathrm{TN} \mu \mathrm{g} / 1$ & $\mathrm{TP} \mu \mathrm{g} / 1$ & $\mathrm{Chl} a \mu \mathrm{g} / 1$ \\
\hline Temperate & 18.2 & 17.4 & 0.96 & 7.4 & 915.7 & 47.4 & 30.6 \\
& $3--73$ & $12--20.7$ & $0.25--1.5$ & $6.5--8.4$ & $340--2090$ & $14--76$ & $2--40$ \\
Subtropical & 20.2 & 21.7 & 0.8 & 7.3 & 735.4 & 63.8 & 19.7 \\
& $3--60$ & $20.7--29$ & $0.3--1.6$ & $5.9--7.8$ & $249--835$ & $21--182$ & $0.8--20$ \\
\hline
\end{tabular}


biomass, most pronouncedly in the subtropical lakes given the stronger predation pressure expected there (Meerhoff et al., 2007a; 2012). We also predicted differences in the number and diversity of macroinvertebrates between both plant types, with outcome depending on the relative importance of complexity (higher for the free-floating plants) and the volume occupied by the plants (higher for the submerged plants). However, within each climate zone we expected macroinvertebrate density to increase with increasing nutrient concentrations and potentially increasing food availability (Blumenshine et al., 1997; Diehl \& Kornijów, 1998), despite variations in fish densities.

\section{MATERIALS AND METHODS}

\section{Design and sampling methodology}

Based on previous information, we paired a set of seven shallow temperate lakes (Denmark: $55^{\circ}-57$ ${ }^{\circ} \mathrm{N}$ ) varying along a trophic gradient (turbidity plus total phosphorus concentration) with a set of similar subtropical lakes (Uruguay: $30^{\circ}-35^{\circ} \mathrm{S}$ ). The lakes were paired according to a series of limnological characteristics (i.e. lake area, mean depth, Secchi disk, macrophyte \% PVI, total phosphorus (TP), total nitrogen (TN), phytoplankton chlorophyll $a$ ( $\operatorname{chl} a$ ), suspended solids, light attenuation, and $\mathrm{pH}$; Table 1). We then ordered the lake pairs along a proxy trophic gradient determined by decreasing water transparency and nutrient concentrations (1-7; seven of the 10 lake sets in the study of fish by Teixeira-de Mello et al. (2009) were included in our study on macroinvertebrates) (Table 1).

Habitat modules resembling submerged and free-floating plant beds (four replicates of each) were introduced in a sheltered and plant-free littoral area of each lake (water depth: 1 meter). The artificial submerged plants and artificial roots of the floating plants consisted of the same plastic material (a total of 80-100 m of garlands made of finely dissected $3.0-\mathrm{cm}$ long pieces per module). The artificial $0.80-1.0-\mathrm{m}$ long submerged plants roughly mimicked the overall structure of Elodea spp., while each artificial free-floating plant consisted of a plastic disc (15 $\mathrm{cm}$ in diameter, 40 per module) to which a total of $2 \mathrm{~m}$ garlands were attached in pieces so as to roughly mimic the root network of water hyacinth, Eichhornia crassipes (Mart) Solms (for photos see Meerhoff et al., 2007b). Local plant volumes inhabited were $49 \%$ and $30 \%$ for submerged and free-floating plants, respectively. Following Tokeshi \& Arakaki (2012), habitat complexity is interpreted as all the different characteristics of structure, thus including spatial scale, size, density, spatial arrangement, and diversity (heterogeneity) of structural elements in an ecosystem. The artificial plants used in this study shared spatial scale, size, and density and varied in two of these complexity components (i.e. spatial arrangement and heterogeneity (length of) structural elements). We used the same habitat modules in both countries after they had been thoroughly rinsed, washed using high water pressure, disinfected with concentrated chlorine solution, and sun-dried.

Sampling campaigns were conducted in summer, four weeks after the introduction of the habitat modules, to allow periphyton and invertebrates to colonize the artificial plants (January 2005 in Uruguay and July 2005 in Denmark; average water temperatures were 25.5 and 18.1 ${ }^{\circ} \mathrm{C}$, respectively). Water samples for the analysis of TP, TN (Valderrama, 1981; Søndergaard et al., 1992, respectively), chl $a$ (Jespersen \& Christoffersen, 1987), and alkalinity were collected from the open water of the lake, where also in situ measurements of Secchi depth, oxygen, $\mathrm{pH}$, temperature, and conductivity (with Horiba field sensors) were conducted. Periphyton biomass was determined as chlorophyll $a$ from a $10-\mathrm{cm}$ long piece of one artificial plant or artificial root taken randomly from each habitat module at 10-20 cm depth from the surface.

Fish and large-bodied low-numbered macroinvertebrates were collected during the night with a cylindrical net (diameter $1.20 \mathrm{~m}$, mesh size $0.3 \mathrm{~cm}$ ), which was placed on the sediment under the habitat modules in the previous afternoon. We approached the modules in a boat and lifted the net in a quick maneuver using a 1.5-m-long stick with a hook. The nets, with the plant modules inside, were removed from the water and carefully inspected. We used an over- 
dose of anesthetic 2-phenoxi-ethanol to euthanize the fish (methodology suggested by the Honorary Animal Research Commission of Uruguay), which were afterwards identified, counted, weighed, and measured (standard length) (Teixeira-de Mello et al., 2009). We used quantitative fish data from Teixeira-de Mello et al. (2009). We sampled the plant-associated macroinvertebrates $(>500 \mu \mathrm{m})$ during the day by carefully removing one artificial plant from each of the habitat modules. Macroinvertebrates were stored in $70 \%$ ethanol and in the laboratory determined to genus level, whenever possible, using different identification keys (e.g. Merritt \& Cummings, 1984). We estimated macroinvertebrate densities as individuals per weight of artificial plant, with the exception of densities of large-bodied (low-numbered) macroinvertebrates, which were included as individuals per $\mathrm{m}^{2}$ of area occupied by plants. We assigned the identified individuals to broad trophic classification according to the literature and measured subsamples of chironomid larvae from all genera under microscope to determine their body size range.

\section{Statistical analyses}

Evenness ( $J$, Pielou's evenness) and diversity ( $H$ ', Shannon diversity) were calculated at the genus level using the formulae: $J=H^{\prime} / \log N$ and $H^{\prime}=-\sum\left(p_{i} * \log p_{i}\right)$, where $p_{i}$ is the fraction of genus $i$ in the sample $\left(n_{i} / N\right)$. The individuals that could not be identified to genus level were included in the calculations of total density and as a single genus (per family) in the diversity, Pielou's evenness, and richness calculations. This conservative method assured that diversity was not boosted by the occurrence of a few individuals that could not be determined to genus level. All dependent variables, except diversity, evenness, and richness, were $\log (\mathrm{x})$-transformed to achieve normality in the dataset. Diversity and evenness were $\mathrm{x}^{2}$-transformed before analyses, and richness was untransformed.

We tested the effects of location (two levels), plant type (two levels), and a proxy of trophic state (seven levels) with a three-factor ANOVA. For post hoc analyses, we used Tukey HSD tests with the Tukey-Kramer adjustment. Dependent
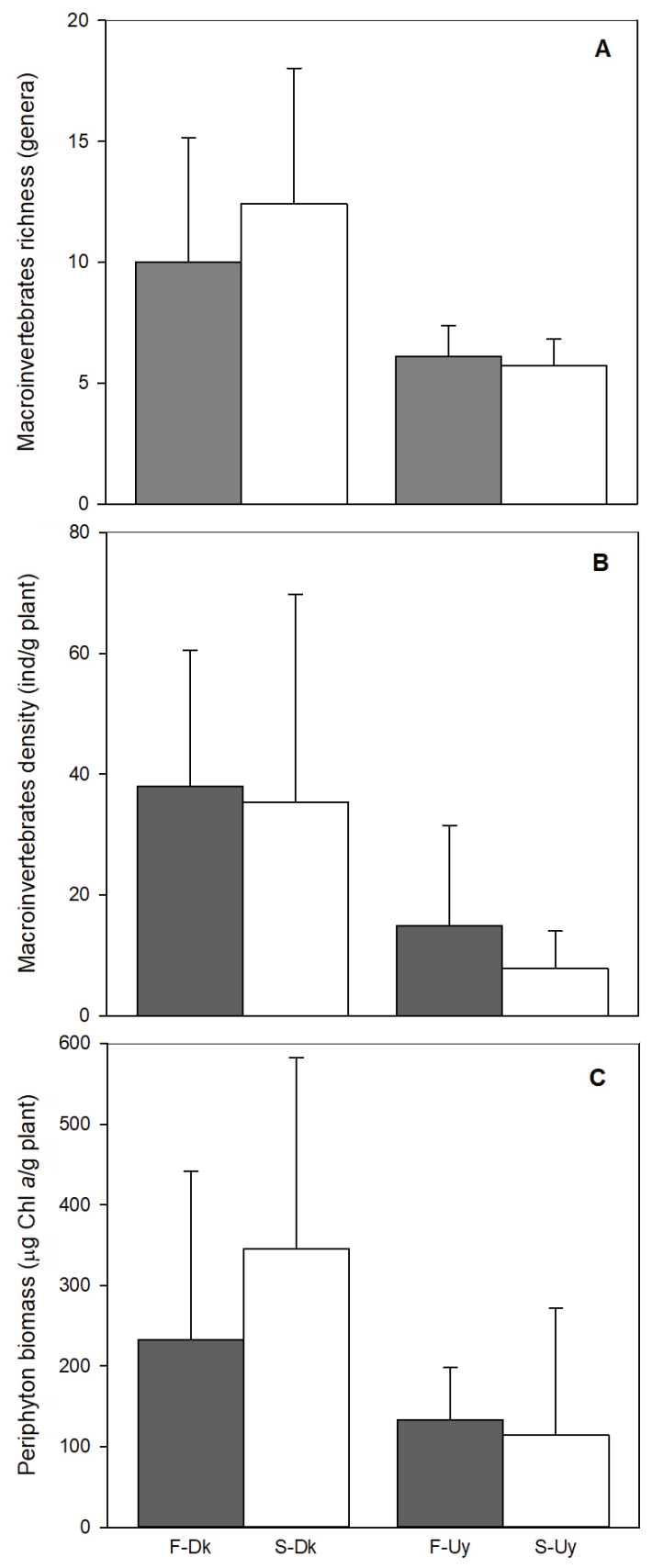

Figure 1. Mean richness of genera (A) and densities (B) of macroinvertebrates, and periphyton biomass (C) in both artificial plant types introduced in temperate (Dk) and subtropical (Uy) shallow lakes. $\mathrm{F}=$ free-floating plants, $\mathrm{S}=$ submerged plants. Data show the average of lake averages and associated standard deviations. Riqueza de géneros (A) y densidades (B) promedio de macroinvertebrados y biomasa de perifiton $(C)$ en ambos tipos de plantas artificiales introducidas en lagos someros templados (Dk) y subtropicales (Uy). $F=$ plantas flotantes libres, $S=$ plantas sumergidas. Los datos muestran el promedio de los promedios de cada lago y el desvío estándar asociado. 
variables included densities of macroinvertebrates per unit of plant biomass ( $g$ artificial plant), diversity, evenness and genera richness of macroinvertebrates, and periphyton biomass.

To facilitate interpretation of the potential habitat use by macroinvertebrates under the different environmental conditions, we estimated the density ratio between the two plant types (i.e. Submerged/Free-floating (hereafter S/F) density ratio). The $\mathrm{S} / \mathrm{F}$ density ratio was calculated for densities of macroinvertebrates per gram of plant, and differences between the two countries were analyzed with one-way ANOVA. Since the overall statistical power was too low to include both countries in the same model, we analyzed variations in the $\mathrm{S} / \mathrm{F}$ density ratio within each country in relation to lake concentrations of $\operatorname{chl} a$, TP and $\mathrm{TN}$, and Secchi disc depth, as well as in relation to mean fish biomass and periphyton biomass as indicators of potential predation pressure and food availability per lake, respectively (i.e. averaging data from the two plant types in each lake). The variables were $\log 10$-transformed before the analyses and tested in simple and multiple linear regressions with stepwise selection retaining variables significant at the 0.05 level (Stepwise selection with $p$-enter: 0.25 and $p$-leave: 0.05 ).

\section{RESULTS}

We found clear differences between the two climate zones in the structure of the macroinvertebrate communities associated with the artificial plants, in terms of taxonomic richness, density, and size structure (Fig. 1 A, B). Diptera was the dominant group in terms of abundance in both countries. Mollusks appeared with higher richness in the temperate lakes than in the subtropical lakes (where only the family Ampullaridae was found). In contrast, large-bodied motile macroinvertebrates, such as apple snails (Pomacea canaliculata Lamarck), shrimps (Palaemonetes cf. argentinus Nobili), and crabs (Aegla sp.), were only found in the subtropical lakes. Apple snails were most abundant in lakes with low nutrient levels. Crabs were only found in the three lakes with the highest fish biomass, while shrimps, the most abundant of the large macroinvertebrates, were absent or very rare in the most eutrophic lakes. Mean $( \pm$ SD) densities were $2.1 \pm 2.6,14.0 \pm 24.2$, and $57.5 \pm 90.3$ ind. $/ \mathrm{m}^{2}$ for apple snails, crabs, and shrimps, respectively, on the free-floating plants, and $6.4 \pm$ 9.3, $19.4 \pm 4.2$, and $103.6 \pm 122.6$ ind. $/ \mathrm{m}^{2}$, respectively, on the submerged plants. Amphipods (Hyalella sp. in Uruguay and Gammarus spp. in Denmark) were found in the lakes with the lowest potential predation pressure, whereas the proportion of oligochaetes rose with increasing fish biomass (with the exception of the Danish lake at trophic level 5, where dipterans were the overall dominant group despite a relatively high fish biomass).

We found a significantly higher richness among the artificial plants in the temperate lakes (see statistical results in Table 2). A total of 36 families and 68 genera occurred there, whereas 19 macroinvertebrate families and 35 genera occurred among the artificial plants of the subtropical lakes (Fig. 1A). We found a total of 19 genera of chironomids (four of which were predators) among the plants in the temperate lakes and only seven in the subtropical lakes. Mean taxonomic diversity was higher in the temperate lakes $(1.87 \pm 0.37$ and $1.13 \pm 0.26$ $($ mean $\pm \mathrm{SD})$ in the Danish and Uruguayan lakes, respectively, Table 2). In contrast to diversity, evenness did not differ significantly between the two climate zones (Pielou's evenness $=0.77 \pm$ 0.09 and $0.64 \pm 0.14$; mean $\pm S D$, in the Danish and Uruguayan lakes, respectively).

Mean density of macroinvertebrates was also significantly higher in the temperate lakes (36.6 \pm 27.9 and $11.4 \pm 12.6$ ind./g plant in Denmark and Uruguay, respectively) (Fig. 1B). The size range of chironomids was broad in the temperate lakes (from 0.5 to $19.0 \mathrm{~mm}$ ), whereas most chironomids in the subtropical lakes had a much narrower body size range (13.0-15.0 mm). Considering macroinvertebrate functional groups, we found ca. 8-fold higher densities of predators, 10-fold higher densities of grazers, and 2-fold higher densities of collectors in the temperate lakes (average of plant types) than in the subtropical lakes.

Regarding our overall hypothesis, we found that macroinvertebrate density was significantly and negatively related to fish biomass in the subtropics, whereas no such relationship occurred 
Table 2. Effects of location (climate zone, C), proxy of trophic state (L), and plant type (P) on littoral macroinvertebrate structure and periphyton biomass, indicating the degrees of freedom (D.F.) and the $\mathrm{F}$ and $p$-values in the three-factor ANOVA tests. Densities of macroinvertebrates per biomass of plants (ind./g of plant) and periphyton biomass ( $\mu \mathrm{g} / \mathrm{g}$ of plant) were $\log (\mathrm{x})$ transformed before analysis. Richness is number of genera. Efectos de la zona climática $(C)$, proxy del estado trófico $(L)$ y tipo de planta $(P)$ sobre la estructura de los macroinvertebrados litorales y biomasa de perifiton, indicando los grados de libertad (D.F.) y los valores de F y $\mathrm{p}$ de las pruebas ANOVA de 3 vías. Las densidades de macroinvertebrados por biomasa de plantas y la biomasa de perifiton por biomasa de plantas fueron transformadas mediante log 10 antes de los análisis. La riqueza refiere al número de géneros.

\begin{tabular}{l|rrr|rrr}
\hline & \multicolumn{3}{|c|}{ Density (ind. g/ plant) } & \multicolumn{3}{c}{ Richness } \\
Explanatory factors & D.F. & $F$ value & \multicolumn{1}{c}{$p$} & D.F. & Fvalue & \multicolumn{1}{c}{$p$} \\
\hline Climate zone (C) & 1,71 & 227.83 & $<0.0001$ & 1,71 & 361.63 & $<0.0001$ \\
Plant Type (P) & 1,71 & 24.09 & $<0.0001$ & 1,71 & 1.53 & 0.2200 \\
Trophic Level (L) & 6,71 & 13.31 & $<0.0001$ & 6,71 & 31.24 & $<0.0001$ \\
C*P & 1,71 & 0.69 & 0.4079 & 1,71 & 5.84 & 0.0182 \\
C*L & 6,71 & 34.38 & $<0.0001$ & 6,71 & 34.88 & $<0.0001$ \\
P ${ }^{*}$ & 6,71 & 3.64 & 0.0033 & 6,71 & 1.92 & 0.0890 \\
C*P L & 6,71 & 5.11 & 0.0002 & 6,71 & 5.36 & 0.0001 \\
\hline
\end{tabular}

\begin{tabular}{l|rrr|rrr}
\hline & \multicolumn{3}{|c|}{ Diversity (H') } & \multicolumn{3}{c}{ Periphyton biomass } \\
Explanatory factors & D.F. & Fvalue & \multicolumn{1}{c}{$p$} & D.F. & F value & \multicolumn{1}{c}{$p$} \\
\hline Climate zone (C) & 1,71 & 229.32 & $<0.0001$ & 1,77 & 70.90 & $<0.0001$ \\
Plant Type (P) & 1,71 & 1.28 & 0.2615 & 1,77 & 2.13 & 0.1488 \\
Trophic Level (L) & 6,71 & 11.81 & $<0.0001$ & 6,77 & 9.20 & $<0.0001$ \\
C*P & 1,71 & 0.00 & 0.9891 & 1,77 & 35.14 & $<0.0001$ \\
$\mathrm{C} * \mathrm{~L}$ & 6,71 & 6.85 & $<0.0001$ & 6,77 & 16.32 & $<0.0001$ \\
$\mathrm{P} * \mathrm{~L}$ & 6,71 & 1.59 & 0.1630 & 6,77 & 3.31 & 0.0060 \\
$\mathrm{C} * \mathrm{P} * \mathrm{~L}$ & 6,71 & 2.93 & 0.0131 & & & \\
\hline
\end{tabular}

in the temperate lakes $\left(\mathrm{R}^{2}=0.70 p=0.018\right.$ and $\mathrm{R}^{2}=0.03 p=0.695$, respectively).

Plant type did not significantly affect diversity and evenness of macroinvertebrates, although a few more families were found on the submerged than on the free-floating plants in both climate zones. However, the overall densities of macroinvertebrates were higher on the free-floating than on the submerged plants (per gram of artificial plant) in most lakes (Table 2). In the Danish lakes, differences were insignificant as we found an average density of $37.9 \pm 22.5$ and $35.3 \pm 34.4$ (mean $\pm \mathrm{SD}$ ) ind./g plant among the free-floating and the submerged plants, respectively, whereas in the Uruguayan lakes we found $14.9 \pm 16.5$ and $7.9 \pm 6.2$ ind./g plant among the free-floating and submerged plants, respectively.

Periphyton biomass was significantly higher in the temperate than in the subtropical lakes (Table 2; $288.7 \pm 222.7$ and $123.6 \pm 116.3 \mu \mathrm{g}$ chl-a/g plant, in Denmark and Uruguay, respectively). Free-floating plants in the subtropics supported a higher biomass of periphyton per unit of weight than did the submerged plants, the opposite being observed in the temperate lakes (significant country $\mathrm{x}$ plant type interaction, Table 2) (232.5 \pm 209.2 and $345.4 \pm 237.2$ (mean \pm SD $\mu \mathrm{g}$ chl-a/g plant) for free-floating and submerged plants in Denmark and 133.2 \pm 64.6 and $114.0 \pm 157.8 \mu \mathrm{g}$ chl- $a / g$ plant for free-floating and submerged plants, respectively, in Uruguay, Fig. 1C).

Plant type had a differential effect on macroinvertebrate density under different environmental conditions in the lakes in the two countries (significant third order interaction in the ANOVA test, Table 2) despite the fact that the mean $\mathrm{S} / \mathrm{F}$ density ratio did not differ significantly between the countries (one-way ANOVA $\mathrm{F}_{1,12}=$ $2.71 ; p=0.125)$. 

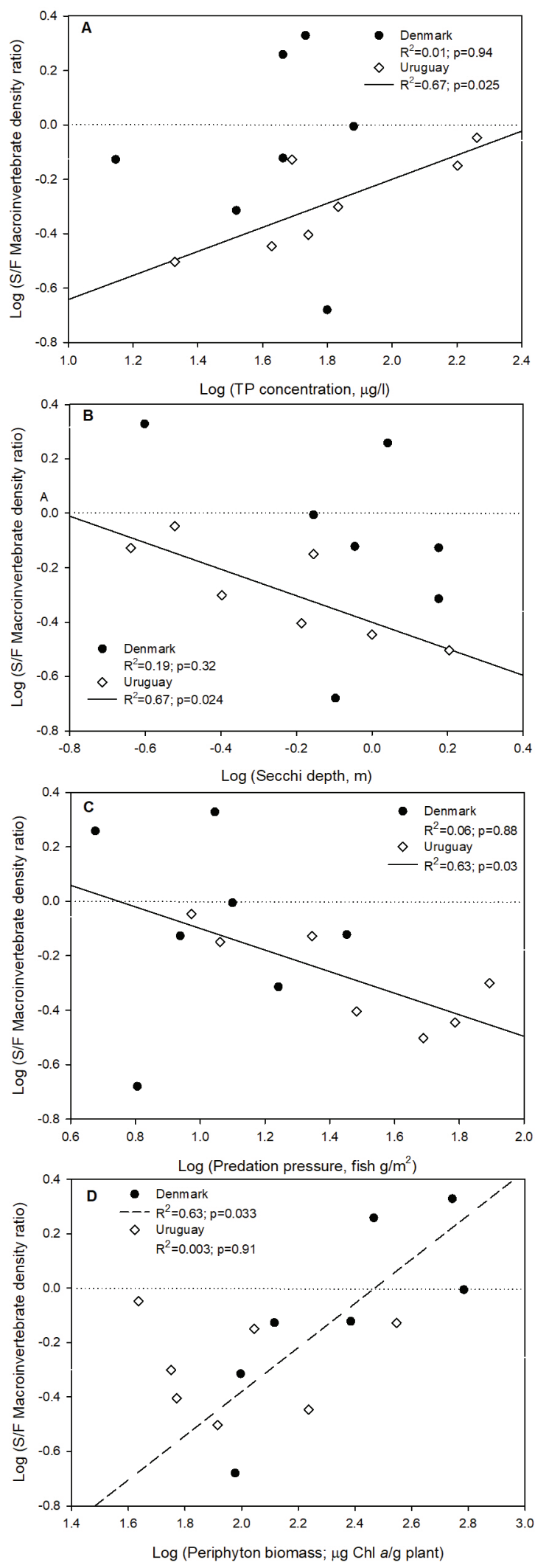

Figure 2. Use of artificial plant by macroinvertebrates (Submerged/Free-floating (S/F) density ratio) in the temperate (Denmark) and subtropical (Uruguay) lakes under different environmental conditions. From top to bottom: A. S/F density ratio and TP concentration, B. S/F density ratio and Secchi depth, C. $\mathrm{S} / \mathrm{F}$ density ratio and potential predation pressure (fish biomass), and $\mathrm{D}$. S/F density ratio and periphyton biomass. Variables were $\log 10$-transformed. All regression statistics are shown, but only the lines of significant regressions are plotted. The dotted line over 0 indicates equal use of free-floating and submerged plants; below 0 use of free-floating plants predominates and vice versa. Uso de las plantas artificiales por los macroinvertebrados (cociente de la densidad entre plantas sumergidas y flotantes libres ( $S / F$ density ratio)) en los lagos templados (Dinamarca) y subtropicales (Uruguay), bajo distintas condiciones ambientales. De arriba abajo: A. Cociente $S / F$ y concentración de PT, B. S Cociente $S / F$ y profundidad de disco de Secchi, C. Cociente $S / F$ y presión de depredación potencial (biomasa de peces), y D. Cociente $S / F$ y biomasa de fitoplancton. Las variables fueron transformadas mediante $\log 10$. Se muestra el resultado de todas las regresiones, pero sólo de las significativas se muestra la línea de regresión. La linea punteada sobre el valor cero indica un uso igualitario entre los tipos de plantas, mientras que valores negativos indican una preferencia por las plantas flotantes libres $y$ viceversa con las sumergidas.

In the subtropical lakes, TP concentration and Secchi depth explained the variation in the $\mathrm{S} / \mathrm{F}$ density ratio equally well (Fig. 2 A, B), but Secchi depth and fish biomass were selected for the final explanatory model (stepwise selection, $\left.\mathrm{R}^{2}=0.90, \mathrm{~F}_{2,4}=18.16, p=0.009\right)$. As Secchi depth, fish biomass had a negative impact on the S/F density ratio (Fig. 2 C), causing larger differences in macroinvertebrate densities between the two plant types towards an even stronger use of free-floating plants with increasing transparency and an increasing potential predation pressure. In contrast, although macroinvertebrate densities were overall not significantly related to periphyton biomass in the temperate lakes, periphyton biomass significantly and positively explained the difference in abundance between plant types (expressed as the S/F density ratio) (Fig. 2 D).

\section{DISCUSSION}

We found distinctly different patterns in community structure, association to different habitat complexities, and relationships with environmental variables of littoral macroinvertebrates between temperate and subtropical regions. 
Because we sampled only the macroinvertebrate assemblages associated with the artificial plants (i.e. littoral), we cannot rule out that other taxa could appear in plant-free or pelagic areas. However, based on works from other systems (e.g. Thomaz et al., 2008; Boll et al., 2012), we do not expect a climate bias in the potentially missing information. Besides, the observed pattern in macroinvertebrate richness was similar to that found for zooplankton in the same field experiment (Meerhoff et al., 2007b), and plausible explanatory mechanisms emerge.

The major differences in the structure of the fish community in shallow lakes between the two climate zones have been identified as the main explanatory factor behind the observed differences in the structure of the potential prey communities (Meerhoff et al., 2007a). Our results suggest that fish are more important than trophic state and local habitat complexity in structuring the richness, composition, and density of plant-associated macroinvertebrates. In both climate zones, amphipods were found in higher proportions in the lakes with the lowest fish biomass, most likely due to their high vulnerability to fish predation (Macneil et al., 1999; Toft et al., 2003). Also, Trichoptera and other insects, excluding Diptera, were found in relatively higher densities in the lakes with the lowest fish biomasses, indicating that these groups are vulnerable to fish predation too. The very narrow body size range of the subtropical chironomids in contrast to the relatively broad size range in the temperate lakes is also consistent with a stronger (and size-selective) predation by fish in the subtropics. In contrast, large-bodied shrimps, snails, and crabs were only found in the Uruguayan lakes and often occurred even at high fish biomass. Apple snails, shrimps, and crabs are large enough to escape predation at least by small fish, allowing for coexistence with the small fishes typically found in the littoral areas of subtropical lakes (Teixeira-de Mello et al., 2009). An equivalent pattern has been recorded in brackish lakes in temperate areas where the shrimp Neomysis integer (Leach) coexists with the small sticklebacks Pungitius pungitius (L.) and Gasterosteus aculeatus (L.) (Jeppesen et al., 1994).

In slight contrast to our results, an experimental study undertaken along a latitudinal gradient in shallow lakes in Europe (Miracle et al., 2006) showed that fish affected the composition rather than the abundance of the plant-associated macroinvertebrate community and that the outcome of the fish-macroinvertebrate interaction depended markedly on the life history traits of the macroinvertebrates (Miracle et al., 2006). However, the fish density in their study was relatively low and fixed in closed mesocosms, while fish were allowed to move freely between the open water and the artificial plants in our field experiment and in a similar experiment conducted by Brucet et al. (2012) in brackish shallow lakes in Denmark and Mediterranean Spain. The difference in the experimental design, with consequent differences in fish density and the potential predation pressure, therefore likely explains the different outcome of these experiments, and the broader impacts of fish detected in this study and in the Mediterranean shallow lakes. The lower macroinvertebrate richness and densities at high fish abundance in the subtropical lakes may result not only from the expectedly greater fish predation there (Teixeira-de Mello et al., 2009; Meerhoff et al., 2012), but also potentially from long-term strong competition with small omnivorous fishes (Flecker, 1992). Small subtropical fish might occupy trophic niches usually used by macroinvertebrates in other regions (Wootton \& Oemke, 1992). Alternatively, as the biomass of periphyton was significantly higher on the artificial plants in the Danish lakes than in the Uruguayan lakes, this greater food availability could lead to a higher abundance of macroinvertebrates in the temperate lakes. However, the stronger role of predation in warmer climates is also evident from the comparative field study of Brucet et al. (2012) in brackish lakes, where drastically lower densities of macroinvertebrates occurred on artificial plants in Mediterranean lakes than in similar temperate lakes despite comparable periphyton biomasses.

Habitat complexity, however, interacts with fish characteristics. Rennie \& Jackson (2005) found that small-scale variation in microhabitat complexity shaped the distribution of littoral macroinvertebrates, but they also found that such effects were systematically different relative to whether fish were present or absent. In their study, greater habitat complexity promoted higher densi- 
ty of macroinvertebrates only in the presence of fish, suggesting that habitat complexity effects are mostly mediated through top-down mechanisms. In a study of 104 shallow cold temperate lakes, fish assemblages explained $>11 \%$ of the among-lake variance patterns in macroinvertebrates despite possible buffering effects by submerged plants (Hanson et al., 2015).

Temperate macroinvertebrates often occur in higher abundance on submerged vegetation than on floating-leaved plants (Cremona et al., 2008; van de Meutter et al., 2008), arguably as a consequence of the higher structural complexity of the former. A comparative study found that the abundance of macroinvertebrates on natural submerged plants did not differ between simple and complex forms, whereas on artificial plants more invertebrates occurred on complex than on simple forms (Taniguchi et al., 2003). In our study the abundance of macroinvertebrates on the artificial submerged macrophytes was almost always lower than on the free-floating macrophytes despite the higher \% PVI of the submerged plant modules. However, variation in free or occupied space sizes has been highlighted as more important for macroinvertebrate taxonomic richness than overall complexity, plant biomass, and density of stems (St. Pierre \& Kovalenko, 2014), and space size was indeed more variable under our artificial floating plant beds than on the more homogenously distributed submerged stems. Along the same line, Thomaz et al. (2008) recorded higher values of surface area available for colonization and fractal dimension (as a measure of complexity) in the root system of the anchored floating plant Eichhornia azurea (Sw.) Kunth than for the submerged Egeria najas Planch, and similar results were found for $E$. crassipes compared with the submerged Cabomba furcata Shult. \& Shult.f. (Matsuda et al., 2015), although such differences did not lead to differences in invertebrate densities.

The greater use of the free-floating plants by macroinvertebrates in the subtropics coincided with a lower use of these plants by the fish there (Teixeira-de Mello et al., 2009). In most temperate lakes, littoral macroinvertebrates were more evenly distributed between the two plant types as shown by an S/F density ratio frequently closer to 1 than in the subtropical lakes despite the greater fish density in the free-floating plant modules (Teixeira-de Mello et al., 2009). This could imply that the artificial free-floating plants acted as an even more effective refuge in temperate lakes or, most likely, that temperate fish prey less heavily on macroinvertebrates than their subtropical counterparts, thus allowing co-existence. The positive relationship between habitat use $(\mathrm{S} / \mathrm{F}$ density ratio) and periphyton biomass in the temperate lakes also suggests that bottom up processes were more relevant there than in the subtropics where top-down processes seemed to rule.

Habitat complexity also interacts with water transparency (Snickars et al., 2004; Pekcan-Hekim \& Lappalainen, 2006), which can influence the fish predation pressure on macroinvertebrates by affecting visually hunting fish (Radke \& Gaupisch, 2005; Pekcan-Hekim \& Lappalainen, 2006). With increasing eutrophication, water turbidity might decrease the importance of plants as an anti-predation refuge. The refuge effect of the free-floating plants in our study was particularly observed under clear water conditions in the subtropical lakes. Perhaps as a consequence of a relatively lower need of refuge, the difference between plant types decreased with lower water transparency.

Free-floating plants are currently more common in warm lakes than in temperate regions, but, as a result of climate warming and increased eutrophication, the geographical distribution of free-floating plants is likely to expand (Scheffer et al., 2003). Fish predation pressure is also expected to augment with climate warming (Meerhoff et al., 2012). Even though we found that patches of free-floating macrophytes may be a comparatively better refuge (or preferred habitat) for macroinvertebrates than submerged plants, free-floating plant dominance in lakes often leads to anoxia and biodiversity loss. Maintenance of a diverse macrophyte community in shallow lakes thus seems important to facilitate coexistence between plant-associated macroinvertebrates and fish and to allow linkage between littoral, benthic, and pelagic habitats.

\section{ACKNOWLEDGEMENTS}

We thank R. Ballabio, L. Boccardi, A. Borthagaray, C. Bruzzone, H. Caymaris, L. Cavada, C. 
Fosalba, G. Goyenola, N. Mazzeo, W. Noordoven, T. Olivera and the personnel of Aguas de la Costa S.A. (in Uruguay), and M. E. Bramm, T. Buchaca, L.S. Hansen, E. Jensen, K. Jensen, F. Landkildehus, T. Larsen, T.L. Lauridsen, K. Stefanidis, J. Stougaard-Pedersen, K. Thomsen, and Y.S. Tunali (in Denmark) for their help during the sampling campaigns. M. Vianna and A. Kröger are thanked for their assistance in macroinvertebrate counting. We thank also A.M. Poulsen for editorial assistance. The landowners and managers are acknowledged for permission to enter the lakes (IMM, MGAP, OSE, Aguas de la Costa S.A., Cabaña Tropicalia S.A. and Rossi family). This work was funded by the Danish Research Agency. EJ was supported by AU Centre of Water Technology. MM, FTM, CI and JMC were also supported by PEDECIBA and the SNI from ANII (National Agency for Research and Innovation), Uruguay.

\section{REFERENCES}

BLUMENSHINE, S. C., Y. VADEBONCOEUR, D. M. LODGE, K. L. COTTINGHAM, \& S. E. KNIGHT. 1997. Benthic-pelagic links: responses of benthos to water-column nutrient enrichment. Journal of the North American Benthological Society, 16: 466-479.

BOLL, T., D., BALAYLA, F.Ø., ANDERSEN \& E. JEPPESEN. 2012. Can artificial plant beds be used to enhance macroinvertebrate food resources for perch (Perca fluviatilis L.) during the initial phase of lake restoration by cyprinid removal? Hydrobiologia, 679:175-186. DOI: 10.1007/S10750-011-0867-1

BRUCET, S. D. BOIX, L.W. NATHANSEN, X. D. QUINTANA, E. JENSEN, D.BALAYLA, M. MEERHOFF \& E. JEPPESEN. 2012. Plant-associated macroinvertebrate community structure in shallow brackish lakes: role of climate, salinity and predation. PLOS ONE, 7(2):e30877.

BRÖNMARK, C. \& J. VERMAAT. 1998. Complex fish-snail-epiphyton interactions and their effects on submerged freshwater macrophytes. in E. Jeppesen, M. Søndergaard, M. Søndergaard \& K. Christoffersen (editors). The Structuring Role of Submerged Macrophytes in
Lakes. Springer-Verlag, New York, USA.

BURKS, R. L., G. MULDERIJ, E. GROSS, I. JONES, L. JACOBSEN, E. JEPPESEN \& E. VAN DONK. 2006. Center stage: the crucial role of macrophytes in regulating trophic interactions in shallow lake wetlands. in $\mathrm{R}$. Bobbink, B. Beltman, J. T. A. Verhoeven \& D. F. Whigham (editors). Wetlands: Functioning, Biodiversity, Conservation, and Restoration. Springer-Verlag, New York, USA.

CATTANEO, A. 1983. Grazing on epiphytes. Limnology and Oceanography, 28: 124-132.

CATTANEO, A., G. GALANTI, S. GENTINETTA \& S. ROMO. 1998. Epiphytic algae and macroinvertebrates on submerged and floating-leaved macrophytes in an Italian lake. Freshwater Biology, 39: 725-740. DOI: 10.1046/j.1365-2427.1998.00325.x

CHERUVELIL, K. S., P. A. SORANNO, J. D. MADSEN \& M. J. ROBERSON. 2002. Plant architecture and epiphytic macroinvertebrate communities: the role of an exotic dissected macrophyte. Journal of the North American Benthological Society, 21: 261-277. DOI: 10.2307/1468414

CREMONA, F., D. PLANAS \& M. LUCOTTE. 2008. Biomass and composition of macroinvertebrate communities associated with different types of macrophyte architectures and habitats in a large fluvial lake. Fundamental and Applied Limnology, 171: 119-130. DOI: $10.1127 / 1863-9135 / 2008 / 0171-0119$

DIEHL, S. \& R. KORNIJÓV. 1998. Influence of submerged macrophytes on trophic interactions among fish and macroinvertebrates. in E. Jeppesen, M. Søndergaard, M. Søndergaard \& K. Christoffersen (editors). The Structuring Role of Submerged Macrophytes in Lakes. Springer-Verlag, New York, USA.

FLECKER, A. S. 1992. Fish trophic guilds and the structure of a tropical stream - weak direct vs strong indirect effects. Ecology, 73: 927-940. DOI: $10.2307 / 1940169$

GONZÁLEZ-SAGRARIO, M. A. \& E. BALSEIRO. 2010. The role of macroinvertebrates and fish in regulating the provision by macrophytes of refugia for zooplankton in a warm temperate shallow lake. Freshwater Biology, 55: 2153-2166. DOI: 10.1111/j.1365-2427. 
2010.02475.X

HAO, B., H. WU, Y. CAO, W. XING, E. JEPPESEN \& W. LI, 2017. Comparison of periphyton communities on natural and artificial macrophytes with contrasting morphological structures. Freshwater Biology, 62: 1783-1793. DOI: 10.1111/fwb.12991

HANSON, M., C. A. BUELT, K. D. ZIMMER, B. R. HERWIG, S. BOWE \& D K. MAURER. 2015. Co-correspondence among aquatic invertebrates, fish, and submerged aquatic plants in shallow lakes. Freshwater Science, 34(3): 953-964. DOI: 10.1086/682118

HARGEBY, A., G. ANDERSSON, I. BLINDOW \& S. JOHANSSON. 1994. Trophic web structure in a shallow eutrophic lake during a dominance shift from phytoplankton to submerged macrophytes. Hydrobiologia, 279-280: 83-90.

JEPPESEN, E., M. SØNDERGAARD, E. KANSTRUP, B. PETERSEN, R. B. ERIKSEN, M. HAMMERSHØJ, E. MORTENSEN, J. P. JENSEN \& A. HAVE. 1994. Does the impact of nutrients on the biological structure and function of brackish and freshwater lakes differ? Hydrobiologia, 275/276: 15-30.

JESPERSEN, A. M. \& K. CHRISTOFFERSEN. 1987. Measurements of chlorophyll- $a$ from phytoplankton using ethanol as extraction solvent. Archiv für Hydrobiologie, 109: 445-454.

JONES, J. I., B. MOSS \& J. O. YOUNG. 1998. Interactions between periphyton, nonmolluscan invertebrates, and fish in standing freshwaters. Pages 69-90 in E. Jeppesen, M. Søndergaard, M. Søndergaard, and K. Christoffersen (editors). The Structuring Role of Submerged Macrophytes in Lakes. Springer-Verlag, New York, USA.

JONES, J. I., \& C. D. SAYER. 2003. Does the fish-invertebrate-periphyton cascade precipitate plant loss in shallow lakes? Ecology, 84: 2155-2167. DOI: 10.1890/02-0422

JONES, J. I. \& S. WALDRON. 2003. Combined stable isotope and gut contents analysis of food webs in plant-dominated, shallow lakes. Freshwater Biology, 48: 1396-1407. DOI: 10.1046/j.1365-2427.2003.01095.x

KOVALENKO, K.E., S. M. THOMAZ \& D. M.
WARFE. 2012. Habitat complexity: approaches and future directions. Hydrobiologia, 685:1-17. DOI 10.1007/S10750-011-0974-Z

LEPPÄ, M., H. HÄMÄLÄINEN \& J. KARJALAINEN. 2003. The response of benthic macroinvertebrates to whole-lake biomanipulation. Hydrobiologia, 498: 97-105.

MACNEIL, C., J. T. A. DICK \& R. W. ELWOOD. 1999. The dynamics of predation on Gammarus spp. (Crustacea : Amphipoda). Biological Reviews, 74: 375-395.

MATSUDA J. T. LANSAC-TÓHA, F. A. MARTENS, K . MACHADO VELHO, L. F. MORMUL, R. P \&. J. HIGUTI. 2015. Association of body size and behavior of freshwater ostracods (Crustacea, Ostracoda) with aquatic macrophytes. Aquatic Ecology, 49:321-331. DOI 10.1007/s10452-015-9527-2.

MEERHOFF, M., J. M. CLEMENTE, F. TEIXEIRA DE MELLO, C. IGLESIAS, A. R. PEDERSEN \& E. JEPPESEN. 2007a. Can warm climate-related structure of littoral predator assemblies weaken the clear water state in shallow lakes? Global Change, Biology, 13: 1888-1897. DOI: 10.1111/j.1365-2486. 2007.01408.x

MEERHOFF, M., C. IGLESIAS, F. TEIXEIRA DE MELLO, J. M. CLEMENTE, E. JENSEN, T. L. LAURIDSEN \& E. JEPPESEN. 2007b. Effects of habitat complexity on community structure and predator avoidance behaviour of littoral zooplankton in temperate versus subtropical shallow lakes. Freshwater Biology, 52: 1009-1021. DOI: 10.1111/j.1365-2427. 2007.01748.X

MEERHOFF., F. TEIXEIRA-DE MELLO, C. KRUK, C. ALONSO, I. GONZÁLEZ-BERGONZONI, J. P. PACHECO, G. LACEROT, M. ARIM, M. BEKLIOĞLU, S. BRUCET, G. GOYENOLA, C. IGLESIAS, N. MAZZEO, S. KOSTEN \& E. JEPPESEN. 2012. Environmental warming in shallow lakes: a review of potential changes in community structure as evidenced from space-for-time substitution approaches. Advances in Ecological Research, 46: 259-349. DOI: 10.1016/B978-0-12396992-7.00004-6

MERRITT, R.W. \& CUMMINS, K.W. 1984. An introduction to the aquatic insects of North 
America. Second ed. Kendall/Hunt Publishing Company, Dubuque, Iowa, 722 pp.

MIRACLE, M. R., B. MOSS, E. VICENTE, S. ROMO, J. RUEDA, E. BÉCARES, C. FERNÁNDEZ-ALÁEZ, M. FERNÁNDEZ-ALÁEZ, J. HIETALA, T. KAIRESALO, K. VAKKILAINEN, D. STEPHEN, L. A. HANSSON \& M. GYLLSTRÖM. 2006. Response of macroinvertebrates to experimental nutrient and fish additions in European localities at different latitudes. Limnetica, 25: 585-612.

MITTELBACH, G. G. 1988. Competition among refuging sunfishes and effects of fish density on littoral zone invertebrates. Ecology, 69: 614-623.

PEKCAN-HEKIM, Z. \& J. LAPPALAINEN. 2006. Effects of clay turbidity and density of pikeperch (Sander lucioperca) larvae on predation by perch (Perca fluviatilis). Naturwissenschaften, 93: 356-359. DOI: 10.1007/ s00114-006-0114-1

PERSSON, L. \& L. B. CROWDER. 1998. Fish-habitat interaction mediated via ontogenetic niche shift. in E. Jeppesen, M. Søndergaard, M. Søndergaard, \& K. Christoffersen (editors). The Structuring Role of Submerged Macrophytes in Lakes. Springer-Verlag, New York.

RADKE, R. \& A. GAUPISCH. 2005. Effects of phytoplankton-induced turbidity on predation success of piscivorous Eurasian perch (Perca fluviatilis): possible implications for fish community structure in lakes. Naturwissenschaften, 92: 91-94. DOI: 10.1007/s00114-0040596-7

RENNIE, M. D. \& L. J. JACKSON. 2005. The influence of habitat complexity on littoral invertebrate distributions: patterns differ in shallow prairie lakes with and without fish. Canadian Journal of Fisheries and Aquatic Sciences, 62: 2088-2099. DOI: 10.1139/ F05-123

SCHEFFER, M., S. SZABÓ, A. GRAGNANI, E. H. VAN NES, S. RINALDI, N. KAUTSKY, J. NORBERG, R. M. M. ROIJACKERS \& R. J. M. FRANKEN. 2003. Floating plant dominance as a stable state. Proceedings of the National Academy of Sciences of the United States of America, 100: 4040-4045.
SCHINDLER, D. E. \& M. D. SCHEUERELL. 2002. Habitat coupling in lake ecosystems. Oikos, 98: 177-189. DOI: 10.1034/j.16000706.2002.980201.X

SNICKARS, M., A. SANDSTROM \& J. MATTILA. 2004. Antipredator behaviour of $0+$ year Perca fluviatilis: effect of vegetation density and turbidity. Journal of Fish Biology, 65: 1604-1613. DOI: 10.1111/j.1095-8649. 2004.00570.x

SØNDERGAARD, M., P. KRISTENSEN \& E. JEPPESEN. 1992. Phosphorus release from resuspended sediment in the shallow and wind-exposed Lake Arresø, Denmark. Hydrobiologia, 228: 91-99.

ST. PIERRE, J. I. \& K. E. KOVALENKO. 2014. Effect of habitat complexity attributes on species richness. Ecosphere, 5(2):22. DOI: 10.1890/ES13-00323.1

TANIGUCHI, H., S. NAKANO \& M. TOKESHI. 2003. Influences of habitat complexity on the diversity and abundance of epiphytic invertebrates on plants. Freshwater Biology, 48: 718-728. DOI: 10.1046/j.1365-2427.2003. 01047.x

TAVSANOĞLU, Ü. N., S. BRUCET, E. LEVI, T. BUCAK, G. BEZIRCI, A. ÖZEN, L. S. JOHANSSON, E. JEPPESEN \& M. BEKLIOGLU. 2015. Size-based diel migration of zooplankton in Mediterranean shallow lakes assessed from in situ experiments with artificial plants. Hydrobiologia, 753: 47-59. DOI: 10.1007/s10750-015-2192-6

TEIXEIRA-DE MELLO, F., M. MEERHOFF, Z. PEKCAN-HEKIM \& E. JEPPESEN. 2009. Substantial differences in littoral fish community structure and dynamics in subtropical and temperate shallow lakes. Freshwater Biology, 54: 1202-1215. DOI: 10.1111/j.1365-2427. 2009.02167.x

TEIXEIRA-DE MELLO, F., DE OLIVEIRA, V.A., LOVERDE-OLIVEIRA, S.M., HUSZAR, V.L.M., BARQUÍN, J., IGLESIAS, C., FREIRE SILVA, T.S., DUQUE-ESTRADA, C.H., SILIÓ-CALZADA, A \& N MAZZEO. 2016. The structuring role of free-floating plants on the fish community in a tropical shallow lake: an experimental approach with natural and artificial plants. 
Hydrobiologia, 778: 167-178. DOI: 10.1007/ s10750-015-2447-2

THOMAZ, S. M., E. D. DIBBLE, L. R. EVANGELISTA, J. HIGUTI \& L. M. BINI. 2008. Influence of aquatic macrophyte habitat complexity on invertebrate abundance and richness in tropical lagoons. Freshwater Biology, 53: 358-367. DOI: 10.1111/j.13652427.2007.01898.x

TIMMS, R. \& B. MOSS. 1984. Prevention of growth of potentially dense phytoplankton populations by zooplankton grazing, in the presence of zooplanktivorous fish, in a shallow wetland ecosystem. Limnology and Oceanography, 29: 472-486. DOI: 10.4319/lo. 1984.29.3.0472

TOFT, J. D., C. A. SIMENSTAD, J. R. CORDELL, \& L. F. GRIMALDO. 2003. The effects of introduced water hyacinth on habitat structure, invertebrate assemblages, and fish diets. Estuaries, 26: 746-758. DOI: 10.1046/j.13652427.2003.01047.x

TOKESHI, M. \& S. ARAKAKI. 2012. Habitat complexity in aquatic systems: fractals and beyond. Hydrobiologia, 685: 27-47. DOI: 10.1007/s10750-011-0832-z

VADEBONCOEUR, Y., M.J. VANDER
ZANDEN \& D.M. LODGE. 2002. Putting the lake back together: reintegrating benthic pathways into lake food web models. Bioscience, 52: 44-54. DOI: 10.1641/0006-3568(2002)052 [0044:PTLBTR]2.0.CO;2

VALDERRAMA, J. C. 1981. The simultaneous analysis of total $\mathrm{N}$ and total $\mathrm{P}$ in natural waters. Marine Chemistry, 10: 109-122. DOI: 10.1016/0304-4203(81)90027-x

VAN DE MEUTTER, F., K. COTTENIE \& L. DE MEESTER. 2008. Exploring differences in macroinvertebrate communities from emergent, floating-leaved and submersed vegetation in shallow ponds. Fundamental and Applied Limnology, 173: 47-57. DOI: 10.1127/1863-9135/2008/0173-0047

WOOTTON, J. T., \& M. P. OEMKE. 1992. Latitudinal differences in fish community trophic structure, and the role of fish herbivory in a Costa Rican stream. Environmental Biology of Fishes, 35: 311-319.

XIE, Z. C., K. MA, R. Q. LIU, T. TAO, C. JING $\&$ S. W. SHU. 2006. Effect of plant architecture on the structure of epiphytic macro invertebrate communities in a Chinese lake. Journal of Freshwater Ecology, 21: 131-137. DOI: $10.1080 / 02705060.2006 .9664105$

Con el apoyo de:

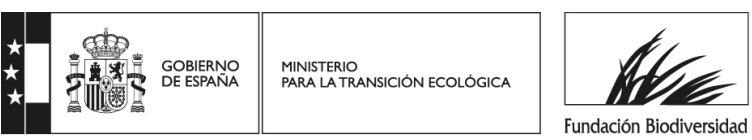

